サイログロブリン合成障害による家族性甲状腺腫の 1 例

信州大学医学部順纯医学研究施設内分泌内科

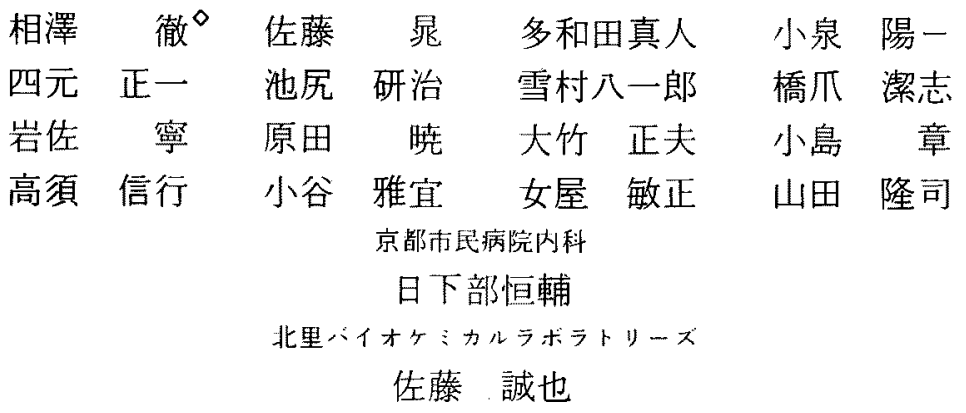

\title{
A CASE OF CONGENITAL GOITER DUE TO IMPAIRED THYROGLOBULIN SYNTHESIS
}

Toru Aizawa, MD, Akira Sato, MD, Masato Tawata, MD, Yoichi Korzumi, MD, Shoichi Yotsumoto, MD, Kenji IKejIrI, MD, Yaichiro Yukimura, MD, Kiyoshi Hashizume, MD, Yasushi Iwasa, MD, Akira Harada, MD, Masao Ohtake, MD, Akira Kojima, MD, Nobuyuki Takasu, MD, Masanobu Kotani, MD, Toshimasa Onaya, MD and Takashi YAMADA, MD

Department of Medicine, Institute of Adaptation Medicine, School of Medicine, Shinshu University

Tunesuke KusakaBe, MD

Section of Endocrinology, Kyoto City Hospital

Seiya Sato, PhD

Kitasato Biochemical Laboratories

摡要 近親婚の子弟で, 20才の男性が構音障害と榎声とを主訴として来院した。身長 $145 \mathrm{~cm}$, 体重 $45 \mathrm{~kg}$, IQ 63 と明らかに身心共に発育障害があり, 甲状腺腫は中等度で柔かく両葉に数個の腫瘤を触九た。 甲状腺機能検查では血中 $\mathrm{T}_{4} 1.7 \mu \mathrm{g} / \mathrm{dl}, \mathrm{BEI} 1.8 \mu \mathrm{g} / \mathrm{dl}$ 之低值にる拘らず，血中 PBIは $8.6 \mu \mathrm{g} / \mathrm{dl}$ と正 常域にあつた。TR HテストではT S Hの過剩分泌が認められ，甲状腺ョード摄取率は高值で血中T は $114 \mathrm{ng} / \mathrm{dl}$ 正常域に保たれていた。甲状腺ホルモン合成障害の部位を明らがする目的で行なつ たパークロレイトテストは陰性, ${ }^{125}$ I-DITを用いた脱ヨード化テストは正常であつた。ささらに甲状腺 組織内の可溶性蛋白を分析したところ，サイログロブリンが15.8\%と著明に少なく，サイロアルブミ ンが $84.2 \%$ と異常高值であつた。一方甲状腺中のペルオキシダーゼ, 蛋白分解酵素の活性は共に正常 域にあつた。 以上の検查結果より，本例の甲状腺ホルモン合成障害はサイログロブリン合成障害によ るむのと判明した。 また，両親は健康で，同胞は性別の如何を問方ず甲状脉腫と発有障害のあるとこ ろから，本例は常染色体性劣性遺伝である事が明らかとなつた。

[昭和50年10月19日 第57回信越地方会推蔗] 


\section{緒言}

家族性甲状腺腫は1897年Osler ${ }^{1)} に よ り$ 初めて報 告され, その後研究が進められた結果, 甲状腺癌 (䯣様癌)，腺腫，慢性甲状腺炎，食慨性因子等によ る家族性甲状腺腫が除外され，今日「先天性酵素 欠損による甲状腺腫」として総括されている22. 酵素欠損にも幾つかのタイプがあり，その程度も 極めて軽度のものから重篤なものに到る迄様々で ある。このため小さな甲状腺腫を有し, Eumetabolicなるの ${ }^{8)}$ から大な甲状腺腫が有り，明らか にhypothyroidになつているもの迄臨床症状は央 に多彩である．このような臨床症状の多彩さに加 党て，酵素欠損そのものを直接証明する事が困難 であるため，「先天性酵素欠損による甲状腺腫」 は全く見逃されているか，あるいは推論されてい ながら診断されす゚に放置されている事が多い.

われわれは最近近親婚の子弟 4 人全員に甲状腺 腫を認め，しかも甲状腺腫が癌，慢性甲状腺炎， 食饋性因子によるものではないと考えられるに到 つたため, 各種の生化学的分析を行ない, その病 態をほら゙明らかにする事ができたのでここにその 概略を報告する。

\section{症例}

患者：20才, 男性, 印刷工.

主訴：構音障害, 㖽声.

家族歴：両親の両親が兄弟同志といら単なる いとこ婚より,さらに濃厚な近親婚の子弟である. 他の同胞 3 人には何れむ患者と同様に甲状腺機能 低下症, 発育陴害, および甲状腺腫があるが, 両親 む含めて他の血縁者には甲状腺疾患はない(図 1 ).

既往歴：13才時䋃径ヘルニア修復術，19才時 虫垂切除術が行なわれた，その他に特記すべき事 はない，著しい便秘や寒がりの傾向はない，

現病歴：生下時体重 $3.5 \mathrm{~kg}$, 生下時甲状腺腫 には気つかれず，歩行開始，発語に遅滞はなかつ た．しかし小学校入学前既に体格は目立つて小さ く，小中学校を通じて 学業成績は極めて 振わな かつた，小学校低学年時より徐々に発語が不明瞭 となり，16才頃から嗄声も加わり耳鼻科医を経て

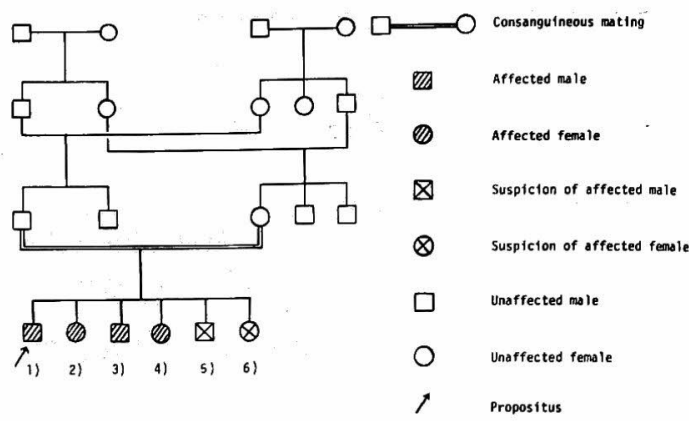

図 1。家族歷，1）本症例，2）22才，甲状腺木 ルモン服用中，3）24才，甲状腺ホルモン服用中， 8 才時甲状腺腫摘除，4）26才，甲状腺ホルモン 服用中, 8 才時甲状腺腫摘除，5）早産で生直後 死亡，6）生後10カ月で死亡（死因不明）

当科に紹介された．甲状腺腫の出現時期は明らか でない.

入院時現症：身長 $145 \mathrm{~cm}$, 体重 $45 \mathrm{~kg}$, 脈拍毎分 90で整, 緊張良好で血圧は102〜60mm 発音は構音障害と㖽声のために聞きとりにくい. 皮膚は正常で著しい乾燥や粘液水腫様変化はな く，粘液水腫反射は認められない。甲状腺腫は中 等度で柔かく，血管雑音を聴取せず, 自発痛, 圧痛 なく, 瘉着もない. 左葉小指頭大のやや硬い腫瘤 を触知するほか，両葉に散在性に小豆大またはそ れ以下の小さな硬い腫瘤を数こ触知した（図 2 ）。 腋毛を全く欠き，恥毛は少なく顔面には殆どひげ を認めない. 頚部, 腋下, 単径部にリンパ節を触知

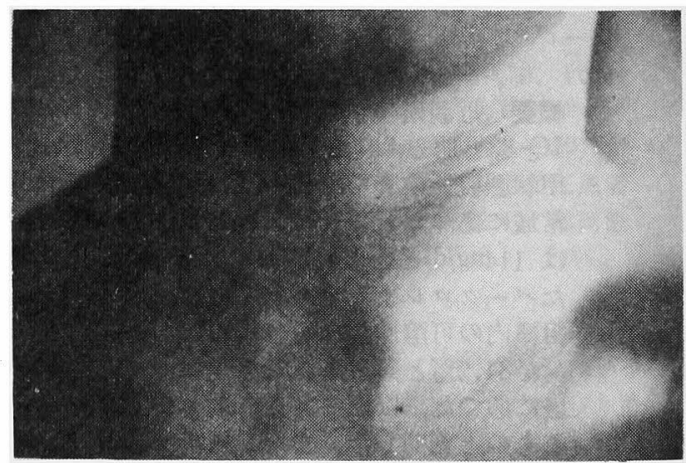

図2.甲状腺腫. 左葉の腫瘤は, 外観からも判然 としている. 
表 1. Laboratory data.

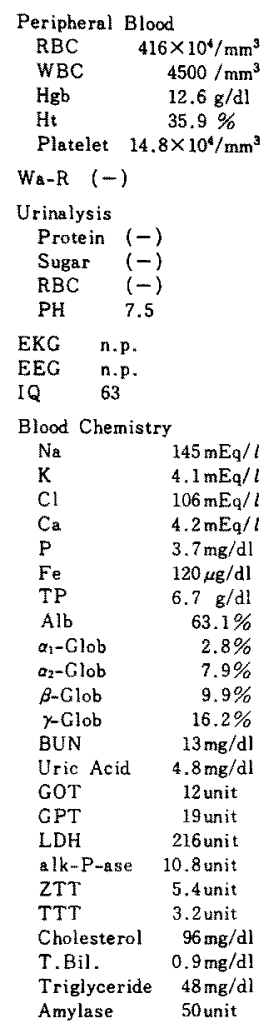

せず，胸部理学的所見では心払大，心雑音等の異 常所見なく，腹部では肝，脾，腎を触知しない。 声帯は耳鼻科的に異常なく，極めて軽度の職業性 難聴があるものの，日常生活に必要な聴力は充分 保たれている. 眼底, 視野, 視力に異常なし.X 線写真でトルコ鞍の容積は $688 \mathrm{~mm}^{3}$ と正常範囲で あつた（正常値250〜800 $\left.\mathrm{mm}^{3}\right)^{5)}$. しかし先天性甲 状腺機能低下症に良く見られるという，大腿骨頭 の不規則な複数の骨化中心が右側に認められた。

\section{入院時検查所見 (表 1 )}

一般的検查: 未梢血, 血清電解質, 蛋白分画 等は全て正常範围内にあり，肝機能および腎機能 正常. 便, 尿に異常なかつた。コレスデロールは 常にやや低值を示した。心電図は正常で低電位な く，脳波は正常であつたが，患者は明らかな知能 発達の障害を有し，I Q b63と著明に低値を示し
表 2. Endocrinological data.

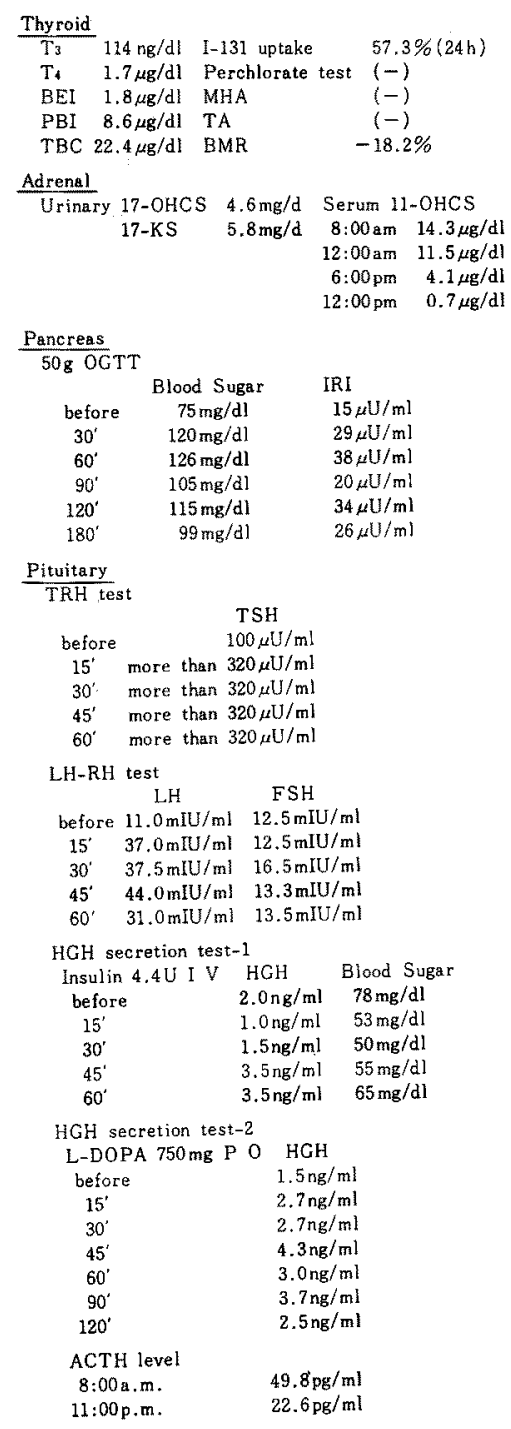

た。

内分泌学的検査 (表 2)：甲状腺機能 検查で は, 血中 $\mathrm{T}_{4} 1.7 \mu \mathrm{g} / \mathrm{dl}, \mathrm{BEI} 1.8 \mu \mathrm{g} / \mathrm{dl}$ と明らかに低 值を示すにす拘らず，P B I が $8.6 \mu \mathrm{g} / \mathrm{dl}$ と正常 值を示した事は極めて特改的な事実であつた。 $\mathrm{T}$ RHテストでは，血中T S H濃度が刺激前 100 $\mu \mathrm{U} / \mathrm{ml}$, 刺激後15分, 30 分, 45分，60分は全て320 $\mu \mathrm{U} / \mathrm{ml}$ 以上と著しい過剩反応を示した。マイタロ 
ゾーム抗体（MH A ), サイログロブリン抗体（ T A ), 共に陰性で甲状腺腫の硬度る橋本病の甲状 腺腫とは全く異なつたものであつた．以上のデー タが甲状腺機能低下を示すにも拘らず，血中 $\mathrm{T}_{8}$ は $114 \mathrm{ng} / \mathrm{dl}$ と正常下界にあり普通の甲状腺機能低下 症とは異なつていた。また ${ }^{131}$ I摂取率は $57.3 \%$ と 高く，パークロ.レイトテストでョードの遊出が殆 ぞなかつた事からョードの取込み，および有機化 の著しい障害はない事が知れた。T B G 結合能 は22.4 $\mu \mathrm{g} / \mathrm{dl}$ と正常範囲にあり， T B G 欠損は除 外できた。．また，全身の脱ヨード化酵素活性を判 定する目的で, ${ }^{125}$ I-DITを静注後, 尿中への

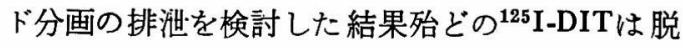
ヨード化されて遊離のヨードとして検出されたた め, 脱ヨード化酵素活性は正常である事が判明し た。これらの検查結果からサイログロブリン合成 障害および絔合障害が最も疑われるところから， 後述する検討を行なつた。

その他の内分泌学的検査ではH G H分泌がregular insulin 4 単位静注に対して前 $2.0 \mathrm{ng} / \mathrm{ml}, 15$ 分後 $1.0 \mathrm{ng} / \mathrm{ml}, 30$ 分後 $1.5 \mathrm{ng} / \mathrm{ml}, 45$ 分後 $3.5 \mathrm{ng} /$ $\mathrm{ml}, 60$ 分後 $3.5 \mathrm{ng} / \mathrm{ml}$ と低值であつた事を除けば 正常範囲内であつた．次いで甲状腺ホルモン合成 障害の存在する段階を明らかにする目的で甲状腺 腫の生検を行なつた。

甲状腺組織の検討： 組織学的には索状または 管状の排列を示す幼若な 腺腫の 部分が 多くを占

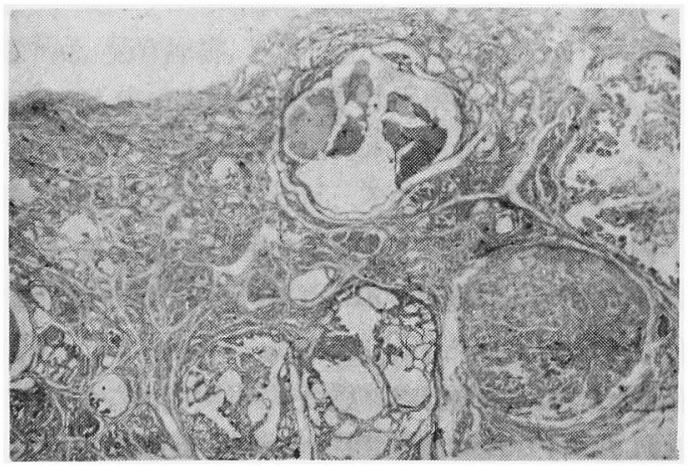

図 3.甲状腺組䅧の光顕像. 纤若な腺腫の部分が 殆どを占めている。
め，一部に濾胞状腺腫が認められたが正常部分は 殆ど認められなかつた（図 3 ).

生化学的分析としてまず可溶性蛋白の分析を行 なつたところ著明な異常が判明した。すなわち患 者甲状腺可溶性蛋白の電気泳動では, サイログロ ブリン分画に泳動する蛋白が，僅か $15.8 \%$ に過ぎ ずフルブミン分画の蛋白が $84.2 \%$ と殆どを占めて いた（図 4).ささらに免疫電気泳動法によつて，こ のアルブミン分画の蛋白の性状を検討した. その 結果, 泳動度は正常ヒト血清アルブミンと等しく, ELECTROPHORETIC PATTERNS OF SOLUBLE PROTEIN
IN THYROID GLAND

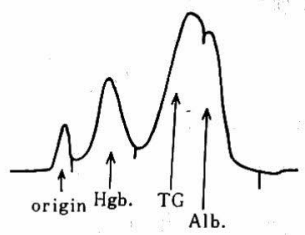

Normal. Thyroid

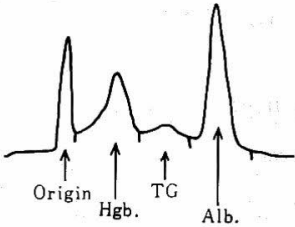

図 4.甲状腺可溶性蛋白の電気泳動。患者甲状腺 では, TG (thyroglobulin) の分画が非常に少ない. $\mathrm{Hgb}$ : hemoglobin, Alb : albumin

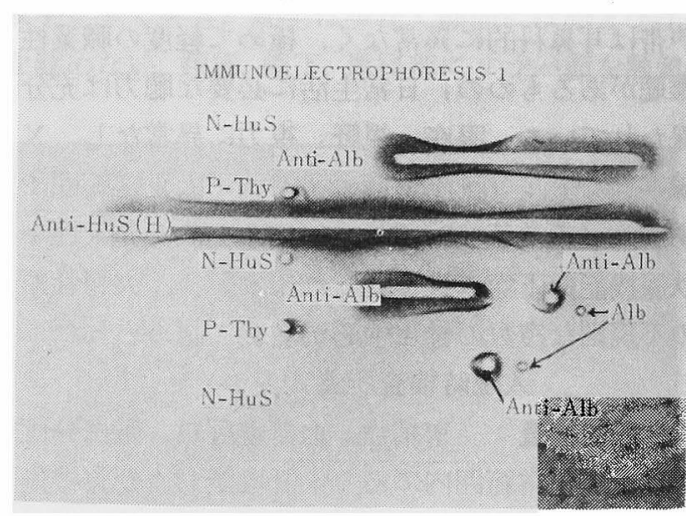

因 5.免疫電気泳動 (1). N-HuS: normal human serum. Anti-Alb: anti-albumin antigen. P-Thy: soluble protein of the patient's thyroid gland. Anti$\mathrm{HuS}(\mathrm{H})$ : anti-human serum antigen 


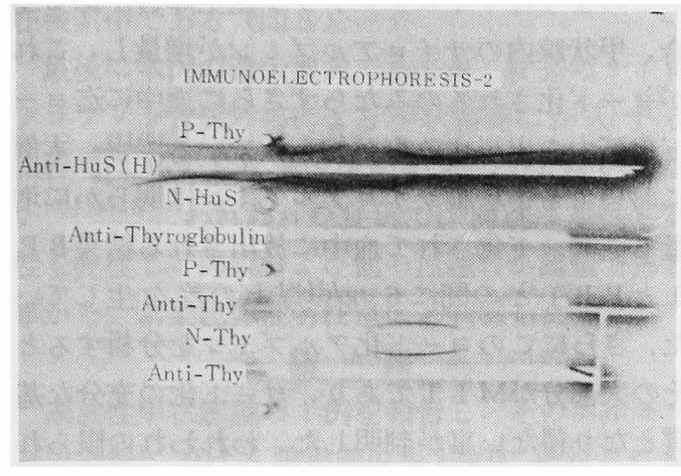

図 6。免疫電気泳動 (2). Anti-Thyroglobulin: anti-thyroglobulin antigenを $10^{6} \mathrm{~K}$ 含む橋本病患者血 清. N-Thy: soluble protein of normal thyroid gland, その他の略号は図 5 に同じ.

抗ヒト血清アルブミン抗体に対する沈降線も正常 ヒト血清アルブミンに対するものと一線に繫がつ た(図 5 ). これらの事実から，患者甲状腺内のア ルブミン分画の蛋白と正常ヒト血清フルブミンと が少なくとも免疫電気泳動法では区別できない事 が知られた。 さらに抗サイログロブリン抗体を $10^{6}$ 倍の濃度に含む橋本病患者血清との間に, この アルプミン分画の蛋白は全く沈降線を形成せず， サイログロブリンとは抗原性の点でも全く共通点 のない事が判明した（図6，7）.

次いで甲状腺組織内の酵素活性を検討したとこ ろ, ベルオキシダーゼ, 蛋白分解酵素の酵素活性 は共に正常範囲内であつた。

血中ヨードの 分析：患者血清中の 総ヨード 量 $8.2 \mu \mathrm{g} / \mathrm{dl}$ で B E I は $1.8 \mu \mathrm{g} / \mathrm{dl}$ であつたところ から，血中に異常ヨード化蛋白の存在が考えられ た. ヨード化蛋白を加水分解した後カラムクロマ トグラフィで分析したところM I T ヨードは 5.9

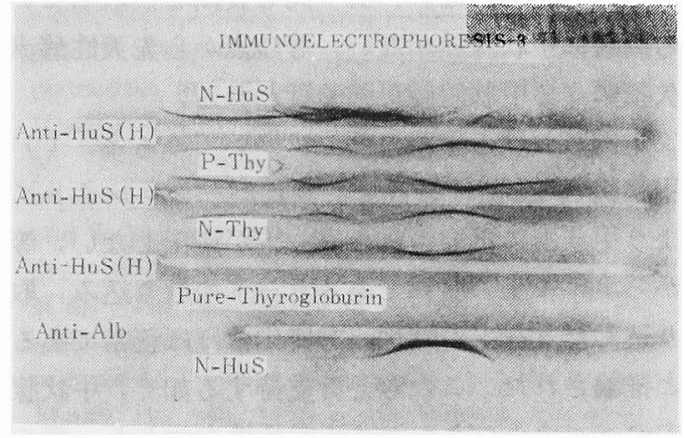

図7. 刍疫電気泳動 (3).略号は図 5, 6k同し.

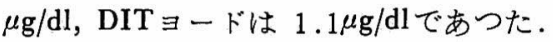

同胞および両親の甲状腺機能（表 3）： 同胞 には程度の差はあるものの全員に甲状腺腫と甲状 腺機能低下症とがあり，すぐ上の姉を除く全員に 著しい発育障害が認められる。両親は臨床的に も，また検査結果からも本疾患を疑わせるものは 全くない。

\section{考案}

先天性酵素欠損による甲状腺腫は, Stanbury2) により，1）ヨードの取込みの障害，2） ヨード の有機化の障害，3） ペンドレッド症候群，4） ヨード化チロジン縮合障害，5）脱ヨード化酵素 異常，6）サイログロブリン合成障害，7）異常 血中ヨード化蛋白を認めるもの，8） T S H V対 する甲状腺の感受性の低下，9） レフェトフ症候 群，10）その他，と障害されている部位がどこか という事に基ついて分類されている.

ここに報告した例は，1）両親が血族結婚であ る，2）兄弟姉妹全員に甲状腺腫がある，3）血 中T S Hが高值で ${ }^{131} \mathrm{I}$ 摂取率が高い，4） MH A， T Aが共に陰性である，5）甲状腺腫の硬度は軟

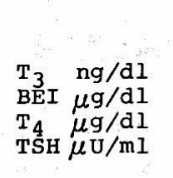

$\begin{array}{rr}\text { 表 3. Thyroid function of } \\ \text { Farther } & \text { Mother } \\ 85 & 102 \\ 4.3 & 3.5 \\ 2.9 & 7.0 \\ 2.4\end{array}$

表 3. Thyroid function of his family members. 
で癌は考えられない，6）同じ食慨を摂取してい る両親に甲状腺腫がない，等の点から先天性酵素 欠損による甲状腺腫が強く疑われる.

本例に拈ける障害の部位についてみると，i） 甲状腺 ${ }^{181}$ 摂取率が高い，ii）パークロレイトに より甲状腺に摂取されたョードが遊出しない，等 からホルモンの原料であるョードの取り込み，取 り込んだョードの酸化，有機化はほぼ正常である と推論された．この考学を支持する如く，甲状腺 内のペルオキシターゼは正常活性を示した。幾つ かの論議はあるが，ペルオキシターゼはヨード化 チロジンの縮合にも関与するとされる77)，多分縮合 反応にもさしたる異常はないものと思われる.さ らに ${ }^{125} I-D I T を$ 用いた検査成績から脱ヨート酵素 系に異常があるとも考えられなかつた ${ }^{889)}$ 。こう した一連の事実から，酵素欠損によるサイログロ ブリン産生障害が最も強〈疑われる(10) 12). この 考えに一致して, 電気泳動法および免疫電気泳動 法によつて甲状腺内にサイログロブリンが極く僅 かしか存在しない事が明らかとなつた．他の兄弟 姉妹について同様な追究を行なつていないが，多 分これら兄弟姉妹全員に酵素欠損によるサイログ ロブリン産生低下があり，この substrateの減少の ために他の酵素活性が正常にも拘らず甲状腺ホル モン産生量が低下して, その結果多量の T S Hが 分泌されて甲状腺腫を引き起こしたものと思われ る.ただ本例の場合問題となる事は, $\mathrm{BEI}, \mathrm{T}_{4}$ が低值にも拘らず血中 $\mathrm{T}_{8}$ は注ぼ正常に保たれてお り， $\mathrm{T}_{4}$ と $\mathrm{T}_{8}$ の間に大きな相違のみられる事であろ う。しかし動物実験などからT S H 刺激により，

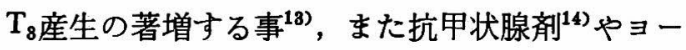
ド欠乏占ににより $\mathrm{T}_{3}$ 産生の著増する事す知られてい る.またヒトです ${ }^{181}$ I治療後のバセドウ病患者, 橋本病患者などでホルモン産生障害が生ずると， $\mathrm{T}_{4}$ が低下するにも拘らず $\mathrm{T}_{3}$ は正常に保たれ，いわ ゆる「 $\mathrm{T}_{3}$-euthyroidism jの状態になる事が知られ ている ${ }^{16)}$. 従つて本例では, $\mathrm{T}_{4}$ 産生障管の代償と してT S Hに過剩刺激された甲状腺で $\mathrm{T}_{\mathbf{8}}$ が多量に 産生されているものと思われる。
このようなサイログロブリン産生障害がある場 合, 甲状腺内のサイロアルブミンが増量し, これ がョード化されるのみならずさらに血中に迄ヨー ト化蛋白の出現する事が知られている ${ }^{10) 11)}$. 本例 においても甲状腺サイロアルブミンは明らかに增 量し, ヨード化されて血中に放出される結果 B E I と P B I との間に $6 \mu \mathrm{g} / \mathrm{d} 1$ 以上の差を生じてい た.さらにこのョード化アルブミンを分析すると その大部分がM I T であり, ヨード化の充分な基 質となり得ない事が判明した．われわれの限られ た研究から，このサイロアルブミンは免疫学的に 血清アルブミンと区別できない事が判明した．従 つてこのサイロアルブミンは血清アルブミンに由 来する可能性もあるが，同時に甲状腺内で産生さ れる可能性も否定できない．何れにしてもサイロ アルブミンがヨード化の充分な基質となり得ない 事は明らかである。

本例でのコレステロールの低値は患者の食䬺か らみて低栄養によるものとは考光難く, 同胞にも 同様にコレステロールの低值がみられるところか ら，家族性低 $\beta$ リポ蛋白血症の合併も疑われ，現

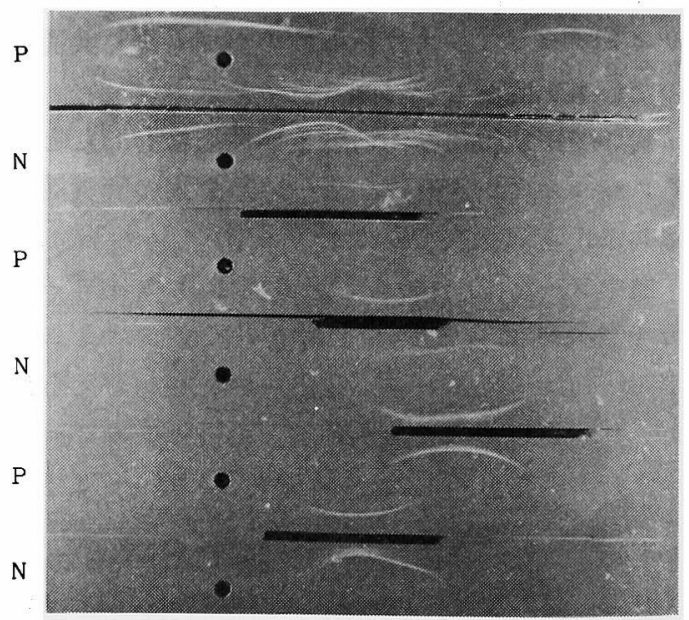

図 8. 患者血清の免疫電気泳動. 抗血清は上から 抗全血清蛋白, 抗 $\beta$ リポ蛋白. 抗セルロブラスミ ン, 抗 $\alpha_{1}$ フンチトリプシン, 抗ハプトプロティン の順上から二段目が $\beta$ 上ポ蛋白の泳動. 正常人 血清に比べて患者血清では $\beta$ リポ蛋白に対する沈 降線が弱い. $\mathrm{P}$ : 患者血清 $\mathrm{N}$ : 正常人血清 
在挨索中である（図 8).

最後に本例の遺伝型式であるが，従来のサイロ グロブリン合成障害による甲状腺嗹にかんする 報告では必ずしも遣伝型式が明らかとはい充な $\left(^{10)-12) 17)}\right.$. われわれの症例では同胞は男性も女 性す発症し，両親および他の血縁者が健康である 事から，常染色体性劣性遗伝と判明した。

\section{轺 語}

家族性甲状腺腫の 1 例を報告し，そのホルモン 合成過程における障害部位を詳細に検討した結 果，サイログロブリン合成障害が基本的な病態で ある事を明らかにし，遗伝型式が常染色体性劣性 遺伝である事を確認した。

\section{文献}

1) Osler, W: Sporadic cretinism in America. Trans Congr Amer, Physicians Surg 4: 169, 1897. 2) 引用. -2) Stanbury, JB et al(ed): The Metabolic Basis of Inherited Diseases. 3rd ed. McGrow Hill, New York, 1972, Familial Goiter. pp 223 265. -3) Clayton, GW et al: Familial goiter with defect in intrinsic metabolism of thyroxine without hypothyroidism. J Pediat 52: 129, 1958. 4) Furth, ED et al: Secretion of iodoalbumin and iodoprealbumin by a congenital goiter containing thyroglobulin and the iodoalbumins. J clin Endocr 31: 60, 1970. -5) 津久井知道, 山田 隆司: 各種内分泌疾患と卜ル马鞍容積. 1.甲状腺 及び下垂体疾患におりるトルコ鞍容積の検討，診 断々治療, $59: 2161,1971 .-6)$ Blasi, F et al: Enzymic pathway for thyroxine synthesis through p-hydroxy-3,5-diiodophenylpyrubic acid. Endocrinol 85: 542, 1969. -7) Taurog, A: Thyroid peroxidase and thyroxine biosynthesis.Rec Prog Hormon Res 26: 189, 1970, -8) Stanbury, JB et al: The metabolism of iodotyrosines. I. The fate of mono- and di-iodotyrosine in normal subjects and in patients with various diseases. J Clin Endocr Metab 16: 735, 1956. -9) Stanbury, JB et al: The metabolism of iodotyrosines. II. The metabolism of mono- and di-iodotyrosine in certain patients with familial goiter. J Clin Endocr Metab 16: 848, 1956. - 10) Riddick, FA et al: Familial goiter with diminished synthesis of thyroglobulin Z Ges Exp Med 150: 203, 1969.-11) Alexander, NM et al: Thyroxine biosynthesis in human goitrous cretinism. J Clin Endocr Metab 30: 308, 1970. -12) Lissitzky, $S$ et al: Congenital goiter with impaired thyroglobulin synthesis. J Clin Endocr Metab 36: 17, 1973. -13) Rabello, MM et al: Effects on the pituitarythyroid axis and prolactin secretion of single and repetitive oral doses of thyrotropin-releasing hormone (TRH). J Clin Endocr Metab 39: 571, 1974. -14) Langer, P: Antithyroid action in rats of small doses of some naturally occurring compounds. Endocrinol 79: 1117, 1966. -15) Greer, MA et al: Qualitative changes in the secretion of thyroid hormones induced by iodine deficiency. Endocrinol 83: 1193, 1968. -16) Williams, $\mathrm{RH}(\mathrm{ed})$ : Textbook of Endocrinology. 5th ed. Saunders, Philadelphia, 1974, The Thyroid Gland $p$ 141. - 17) Werner, SC et al(ed): The Thyroid. 3rd ed. Harper \& Row, New York, 1971. Genetic Factors in Thyroid Disease. pp 383 405. 